\title{
Effect of Intralumenal Cation-Exchange Resin on Excretion of Ammonia in Rat Ileum
}

\author{
KATHLEEN B. SCHWARZ, ${ }^{(29)}$ IRENE E. KARL, AND DAVID H. ALPERS
}

\author{
Department of Pediatrics, Division of Pediatric Gastroenterology, St. Louis University School of Medicine [K.B.S.] \\ and Department of Medicine, Divisions of Gastroenterology and Metabolism, Washington University School of \\ Medicine [I.E.K., D.H.A.], St. Louis, Missouri, USA
}

\begin{abstract}
Summary
Ammonia excretion was studied in rat ileal segments during perfusion of the animal through the saphenous vein. In the first 10 min during and after intravenous infusion of $\mathrm{L}$-glutamine $(116 \mathrm{mg} /$ $\mathrm{kg}$ to double arterial glutamine concentration) average net change in lumenal ammonia was $13 \pm 8$ (S.E.) $\mathrm{nmole} \mathrm{NH}_{3} / \mathrm{min} / \mathrm{g}$ ileum; average net change in ileal venous ammonia was $28 \pm 9$ nmole $\mathrm{NH}_{3} / \mathrm{min} / \mathrm{g}$ ileum; and average net change in total ammonia (lumen + ileal vein) was $41 \pm 13$ compared to $-5 \pm 10$ nmole/ $\mathrm{min} / \mathrm{g}$ ileum for animals infused with saline $P<0.025$. These data suggest that ileal metabolism of arterial glutamine liberates ammonia to both ileal venous blood and intestinal lumen. When a cation-exchange resin which binds ammonia was infused intralumenally, average net change in lumenal ammonia in the first $\mathbf{1 0}$ min during and after intravenous infusion of $116 \mathrm{mg} / \mathrm{kg} \mathrm{L-gluta-}$ mine was $415 \pm 156$ nmole $\mathrm{NH}_{3} / \mathrm{min} / \mathrm{g}$ ileum $(\mathrm{p}<0.01$ compared to value during perfusion of Earle's solution alone). During the first 10 min during and after glutamine infusion net change in ileal venous plasma ammonia was $-8 \pm 14$ when resin was being perfused through the lumen compared to $+28 \pm 9 \mathrm{nmole} / \mathrm{min} / \mathrm{g}$ ileum during perfusion of Earle's solution alone without resin $P$ $<0.05$. Thus resin in the small intestine can trap very large amounts of ammonia.
\end{abstract}

\section{Speculation}

Ammonia-binding cation-exchange resins may be useful therapeutically in lowering portal venous ammonia and increasing intestinal ammonia excretion in patients with hyperammonemia.

The management of chronic hyperammonemia in the pediatric patient has been limited to dietary protein restriction which may result in malnutrition(4), antibiotic administration, which may result in oto-and neurotoxicity, lactulose administration with resultant diarrhea, and feeding of the very expensive keto-analogues and hydroxy-analogues of essential amino acids(1). Alternative or adjunctive therapy is desirable, as is more knowledge about the sources and distribution of ammonia in the body. Herein we investigate ileal metabolism of glutamine as a source of ammonia and show that an intralumenal cation-exchange resin can lower intestinal venous ammonia.

Although the colon has long been recognized as a major source of ammonia in mammals, including man $(17,18)$, the small intestine is also capable of ammonia absorption (9) and secretion (13). Summerskill and Wolpert (18), on the basis of steady-state basal ammonia output from perfusion studies, estimated that jejunum and ileum generated one-quarter of the ammonia produced in the gastrointestinal tract of healthy man. Possible sources of ammonia in the small intestinal lumen include mucosal urease (19) and both ammonia (15) and glutamine (23) in arterial blood.

Glutamine metabolism by intestine appears to be a quantitatively important source of ammonia in intestinal venous drainage.
Glutamine is the most abundant amino acid in mammalian plasma. In the rat it is an important respiratory fuel for the intestine, as intestinal metabolism of arterial glutamine provides approximately 35 to $45 \%$ of the $\mathrm{CO}_{2}$ produced by the organ (24, $25)$. Windmueller and Spaeth (24) have demonstrated that in an isolated vascularly perfused segment of jejunum, ammonia released into venous blood accounted for approximately $80 \%$ of glutamine taken up on a mole-for-mole basis.

We have previously shown that an intravenous bolus of glutamine increases both venous and lumenal ammonia in an isolated vascularly perfused ileal segment of rat (16). Studying the dog, Weber and Veach (22) showed that small intestine accounted for $50 \%$ of the total ammonium released into intestinal venous blood from jejunum, ileum, and colon. The release of ammonium was directly related to the uptake of glutamine.

Herein, we present data regarding ammonia accumulation in rat ileal lumen and further demonstrate that in the hyperglutaminemic state, an intralumenal cation-exchange resin which binds ammonia can markedly increase lumenal ammonia. Of possible therapeutic significance is the observation that the rise in ileal venous plasma ammonia usually observed after intravenous glutamine is abolished by an intralumenal cation-exchange resin.

\section{MATERIALS AND METHODS}

\section{RATS AND DIETS}

Sprague-Dawley rats fed Ralston Purina Rat Chow were used. Intestine donors were males weighing 330 to $470 \mathrm{~g}$ and were fasted overnight. Blood donors were nonfasted adult rats.

\section{ILEAL SEGMENT PREPARATION}

Ileal segments were prepared in a fashion similar to the Windmueller and Spaeth (26) jejunal segment preparation. In our experiments the Earle's balanced salt solution bathing the gut serosa contained $11.1 \mathrm{mM}$ glucose and $0.6 \mathrm{mM}$ glutamine. (Com-

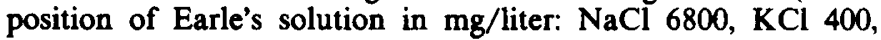
$\mathrm{CaCl}_{2}: \mathrm{H}_{2} \mathrm{O} 265, \mathrm{MgSO}_{4}: 7 \quad \mathrm{H}_{2} \mathrm{O} \quad 200, \mathrm{NaH}_{2} \mathrm{PO}_{4}: \mathrm{H}_{2} \mathrm{O} \quad 140$, and phenol red $0.01 \mathrm{~g} /$ liter.) The solution perfusing the lumen was Earle's solution alone without added glutamine or glucose. Both inflow and outflow lumenal cannulae were used with each segment. In most experiments, the ileal vein but not the segmental artery was cannulated. Sodium heparin $(2.5 \mathrm{mg}$ in $0.15 \mathrm{ml}$ normal saline) was infused into the saphenous vein to anticoagulate the animal before cannulation of the aorta and segmental ileal vein. The intestinal lumen was flushed for at least $15 \mathrm{~min}$ (or longer if needed to produce a clear effluent) with Earle's solution before beginning each experiment. Lumenal $\mathrm{pH}$ was sampled periodically; $\mathrm{pH}$ range was 7.0 to 7.4 . Each experiment was begun immediately after the segmental ileal vein was cannulated. Donor blood was infused through the saphenous vein at a rate sufficient to maintain initial blood pressure. Saline alone or with added glutamine was infused in the saphenous vein as noted in the 
discussion of the various experiments. The animal was warmed by a heat lamp to maintain rectal temperature above $36.5^{\circ} \mathrm{C}$. At the conclusion of the perfusion the ileal segments remained pink; histologic examination revealed intact mucosa.

\section{RESIN PREPARATION}

Since the smallest available resin bead, 200 to 400 mesh, settles out of solution within a few minutes, special preparation of the resin was necessary to produce a resin fine enough to remain in suspension for the duration of the experiment. Dowex $50 \mathrm{~W} \times 8$ (200 to 400 mesh) (Sigma Chemical Co., St. Louis, MO) strongly acidic cation-exchange resin was vacuum-dried for $72 \mathrm{hr}$ and then steel-ball milled for $72 \mathrm{hr}$. An aliquot of resin was mixed 1:10 with tap water and allowed to settle. Resin remaining in suspension after $1 \mathrm{hr}$ was converted to the sodium form (10) and stored in 4 $\mathrm{M} \mathrm{NaCl}$ at $4^{\circ} \mathrm{C}$. For each experiment resin was washed with six bed volumes of fresh $4 \mathrm{M} \mathrm{NaCl}$ followed by six volumes of deionized water and mixed 1:100 with fresh Earle's balanced salt solution.

\section{RESIN PERFUSION}

Five-milliliter syringes were filled with the fresh resin in Earle's solution at the beginning of a perfusion. The resin solution was perfused through one arm of a Y-tubing attached to the lumen inflow catheter, the other arm of the $Y$ being attached to tubing coming from the Earle's solution. One arm of the $Y$ tubing was primed with resin at the beginning of an experiment. During each $10-\mathrm{min}$ period of resin perfusion, $5 \mathrm{ml}$ of the resin solution were perfused. The gut was flushed two times with $2.5 \mathrm{ml}$ Earle's solution at the end of each $10 \mathrm{~min}$. Two of the $5-\mathrm{ml}$ syringes were used as blanks, one being processed at the beginning of the experiment and the other at the experiment's conclusion, having been allowed to stand in room air during the experiment. This was done to correct for possible adsorption by the resin of ammonia from room air.

\section{FLOW RATES}

Flow rates were determined gravimetrically. Average ileal venous flow rate varied from 0.09 to $0.15 \mathrm{ml} / \mathrm{min}$. Average lumenal flow rate varied from 0.3 to $0.8 \mathrm{ml} / \mathrm{min}$. Since the average segment weight was $0.4 \mathrm{~g}$, venous flow ranged from about 0.2 to $0.4 \mathrm{ml} /$ $\mathrm{min} / \mathrm{g}$ and lumenal flow from about 0.8 to $2.0 \mathrm{ml} / \mathrm{min} / \mathrm{g}$ ileum.

\section{SAMPLES}

Ileal venous and intestinal lumen samples were collected continuously at 5 to 10 -min intervals. Aorta samples were collected at the beginning of the lumenal perfusion period, the beginning and end of the 5-min glutamine infusion period, and every 5 to $20 \mathrm{~min}$ thereafter depending on the experiment. Plasma was separated from blood immediately after each specimen was collected, quickfrozen, and stored at $-70^{\circ} \mathrm{C}$. Samples were analyzed within $72 \mathrm{hr}$, since previous work had demonstrated sample stability within that time limit (10). Duplicate analyses were performed on all samples from aorta and lumen, and also on ileal venous samples when volume permitted.

\section{CHEMICAL DETERMINATIONS}

Ammonia determinations on plasma and lumenal fluid were done according to Oberholzer et al.(9). Standard deviation of 15 samples of $102 \mu \mathrm{mole} /$ liter was $6 \mu$ mole/liter. Standard deviation for 21 samples of that same standard analyzed over 1 month's time was $6 \mu \mathrm{mole} / \mathrm{liter}$. Ammonia bound to resin was assayed by trapping the resin on $1.2 \mu$ Millipore filters (Millipore Co., Bedord, $\mathrm{MA}$ ) and using the filters in place of the micro-columns in the Oberholzer assay. Plasma and lumenal fluid glutamine was determined enzymatically and micro-fluorometrically using Escherichia coli L-glutamine amidohydrolase EC 1.5.1.2 (5).

\section{CALCULATIONS}

Ileal glutamine extraction was calculated by the aorta venous plasma glutamine concentration difference $\times$ the ileal venous flow rate ( $\mathrm{ml} / \mathrm{min} / \mathrm{g}$ ileum). Lumenal ammonia was determined by the lumenal ammonia concentration $(\mathrm{nmole} / \mathrm{ml}) \times$ the lumen flow rate $(\mathrm{ml} / \mathrm{min} / \mathrm{g}$ ileum). Ileal venous plasma ammonia was expressed as plasma concentration $(\mathrm{nmole} / \mathrm{ml}) \times$ the flow rate $(\mathrm{ml} /$ $\mathrm{min} / \mathrm{g}$ ileum). Mean base line values (before intravenous infusion of glutamine or saline) are expressed as nmole $/ \mathrm{min} / \mathrm{g}$ ileum and were calculated for the group as the average of the mean base line values for individual animals. The mean base line for each animal was calculated from three 5-min samples collected from the 5th to the 20th min of perfusion of the ileum with Earle's solution. (The first 5-min blood samples were considered to be subject to contamination and were not included in the analysis). Peak value refers to the peak 5 -min period (expressed as nmole $/ \mathrm{min} / \mathrm{g}$ ileum) in each animal in the 20 min during and after intravenous infusion of saline or glutamine, regardless of when the peak occurred. Net data were derived by subtracting mean baseline for each animal from the various postglutamine or saline infusion values (0 to 10 min, peak, and 0 to $20 \mathrm{~min}$; see Table 1 ).

\section{STATISTICAL ANALYSIS}

The nonpaired, one-tailed $t$ test was used for all comparisons. Comparisons were made between glutamine- and saline-treated animals, and between glutamine-infused animals in the presence or absence of intralumenal resin. Data are expressed as the mean \pm S.E.

\section{RESULTS}

Preliminary studies indicated that the ileal segment preparation itself did not increase the production of ammonia in either lumen

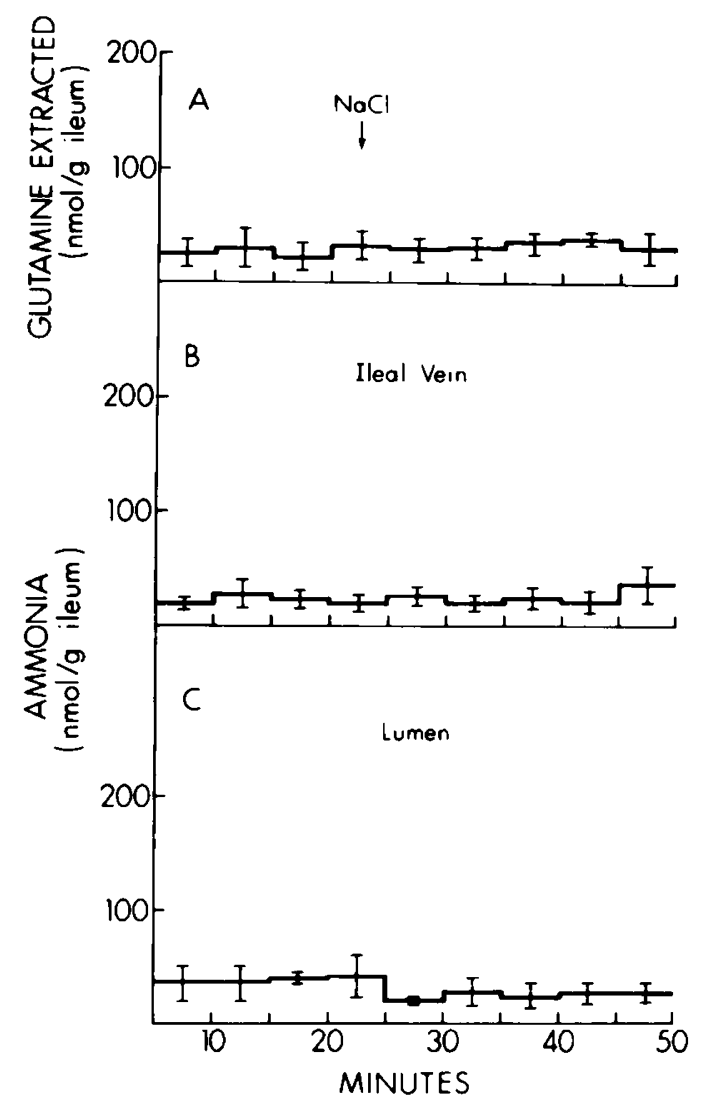

Fig. 1. Average glutamine extraction $(A)$, ileal venous ammonia $(B)$, and lumenal ammonia $(C)$ for five animals receiving $3.0 \mathrm{ml}$ of $0.9 \% \mathrm{NaCl}$ in the saphenous vein at 20 to $25 \mathrm{~min}$ of perfusion of the lumen with Earle's solution. Results are expressed as mean \pm S.E. for five animals for each 5-min period. 
or ileal vein during $45 \mathrm{~min}$ of perfusion. In two rats in whom neither glutamine nor saline was added to the continuous transfusion of homologous blood into the saphenous vein, average lumenal $\mathrm{NH}_{3}$ at 0 and $30 \mathrm{~min}$ of perfusion of the lumen with Earle's solution was 35 and $34 \mathrm{nmole} / \mathrm{ml}$, respectively. In five rats after a 20 -min base line perfusion of the lumen with Earle's solution, $3 \mathrm{ml}$ of $0.9 \%$ saline were infused in the saphenous vein over a 5 -min period. Results, shown in Figure 1, indicate that

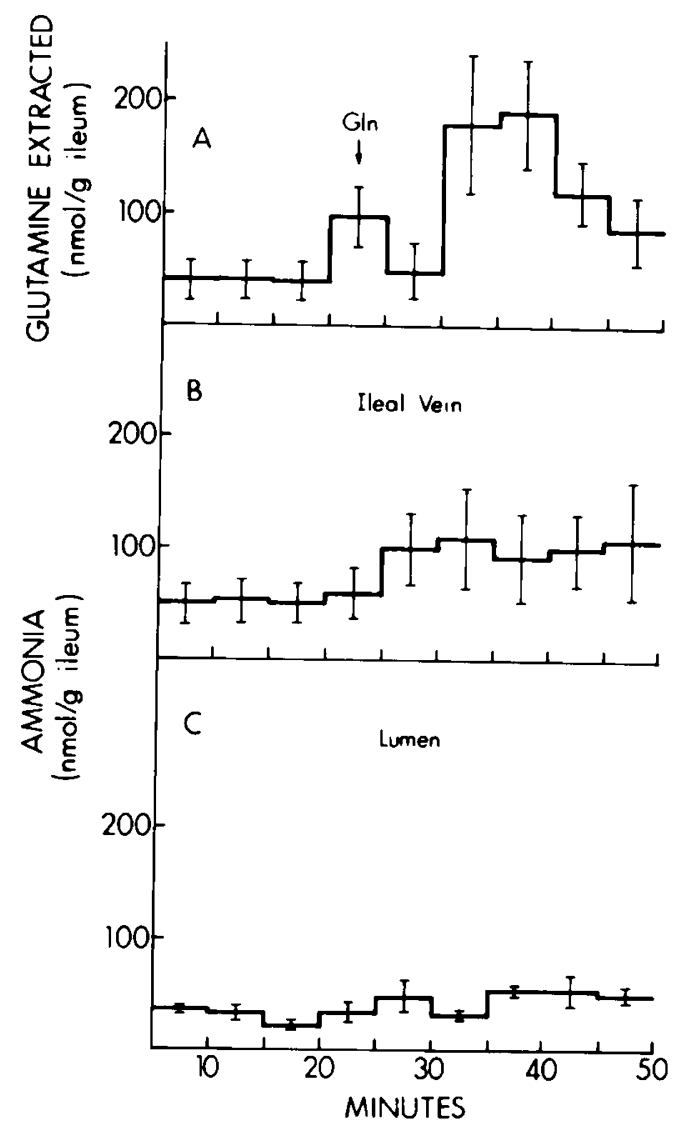

Fig. 2. Average glutamine extraction $(A)$, ileal venous ammonia $(B)$, and lumenal ammonia $(C)$ for six animals receiving $116 \mathrm{mg} / \mathrm{kg} \mathrm{L-glutamine}$ $(\mathrm{Gln})$ in $3.0 \mathrm{ml}$ of $0.9 \% \mathrm{NaCl}$ in the saphenous vein at 20 to $25 \mathrm{~min}$ of perfusion of the lumen with Earle's solution. Results are expressed as mean \pm S.E. for six animals for each 5-min period. neither lumenal nor ileal venous ammonia increased in the $25 \mathrm{~min}$ after saline infusion. Similarly glutamine extraction from blood did not change.

\section{PERFUSION WITHOUT RESIN}

Six rats received $116 \mathrm{mg} / \mathrm{kg} \mathrm{L-glutamine} \mathrm{in} \mathrm{the} \mathrm{saphenous} \mathrm{vein}$ over $5 \mathrm{~min}$, after a 20 -min base line perfusion of the lumen with Earle's solution. This amount of glutamine raised the arterial plasma glutamine concentration at the end of the 5 -min infusion to 2 to 3 times base line values. Figure 2 records average results for each 5-min period during perfusion. Average maximal lumenal ammonia occurred 10 to $20 \mathrm{~min}$ after glutamine infusion, and was 1.7 times the average base line value. Similarly, maximal glutamine extraction by the ileal segment occurred 10 to 15 min after infusion of glutamine and was almost five times the average base line values. Ileal vein ammonia averaged for the entire preinfusion baseline was $21 \pm 7$ and $48 \pm 17 \mathrm{nmole} / \mathrm{min} / \mathrm{g}$ ileum for the experiments depicted in Figures 1 and 2, respectively. These values correspond well with the average amount of glutamine extracted in each preinfusion base line $(23 \pm 14$ and $39 \pm 16 \mathrm{nmole} / \mathrm{min} / \mathrm{g}$ ileum, respectively), suggesting that deamidation of glutamine could account for almost all of ileal venous ammonia. The average base line lumenal ammonia in Figures 1 and 2 (38 \pm 13 and 30 $\pm 4 \mathrm{nmole} / \mathrm{min} / \mathrm{g}$ ileum, respectively) could have resulted in part from the action of bacterial and mucosal ureases on urea, since the animals were not germ free.

Table 1 records net changes in ammonia production and glutamine extraction during perfusion of the lumen with Earle's solution. Glutamine infusion into the saphenous vein resulted in significant increases in net ammonia in ileal venous blood compared to saline-infused animals.

The average increase in glutamine extraction in the first $20 \mathrm{~min}$ following glutamine infusion, $86 \pm 40 \mathrm{nmole} / \mathrm{min} / \mathrm{g}$ ileum, could account for all the increase in ammonia measured in ileal venous plasma and lumenal fluid $(34 \pm 20$ and $12 \pm 5 \mathrm{nmole} / \mathrm{min} / \mathrm{g}$ ileum, respectively). Fifty-three percent of the ammonia produced by ileal metabolism of glutamine (46 of 86 nmole glutamine/min/ g ileum) could be accounted for as free $\mathrm{NH}_{3}$ in the ileal vein and lumen. Seventy-two percent of ammonia produced by intestinal mucosa (34 of $46 \mathrm{nmole} \mathrm{NH}_{3} / \mathrm{min} / \mathrm{g}$ ileum) was in the venous plasma and $28 \%$ in the lumen. Interestingly, although arterial plasma glutamine concentration after glutamine infusion was as high as $1500 \mathrm{nmole} / \mathrm{ml}$ (normal $=500$ to $600 \mathrm{nmole} / \mathrm{ml}$ ) only barely detectable amounts of glutamine were found in the lumenal fluid.

Table 1. Net ammonia recovery and glutamine extraction during lumenal perfusion with Earle's solution ${ }^{1}$

\begin{tabular}{|c|c|c|c|c|c|}
\hline \multirow[b]{2}{*}{$\begin{array}{l}\text { Intravenous infu- } \\
\text { sion }\end{array}$} & \multirow[b]{2}{*}{$\begin{array}{c}\text { Collection time } \\
(\mathrm{min})\end{array}$} & \multicolumn{3}{|c|}{ Ammonia recovered } & \multirow[b]{2}{*}{$\begin{array}{l}\text { Glutamine extracted } \\
\text { (nmole } / \mathrm{min} / \mathrm{g} \text { ileum) }\end{array}$} \\
\hline & & $\begin{array}{c}\text { Ileal vein } \\
\text { (nmole/min/g } \\
\text { ileum) }\end{array}$ & $\begin{array}{c}\text { Lumen } \\
\text { (nmole/min/g ileum) }\end{array}$ & $\begin{array}{l}\text { Total (vein + lumen) } \\
\text { (nmole/min/g ileum) }\end{array}$ & \\
\hline \multirow[t]{3}{*}{ Glutamine } & $0-10^{2}$ & $28 \pm 9^{3}$ & $13 \pm 8$ & $41 \pm 13^{3}$ & $38 \pm 28$ \\
\hline & Peak & $59 \pm 25$ & $42 \pm 10^{4}$ & $101 \pm 33^{4}$ & $158 \pm 60^{4}$ \\
\hline & $0-20^{5}$ & $34 \pm 20$ & $12 \pm 5$ & $46 \pm 18^{3}$ & $86 \pm 40$ \\
\hline \multirow[t]{3}{*}{ Saline } & $0-10^{2}$ & $-2 \pm 2$ & $-3 \pm 7$ & $-5 \pm 10$ & $5 \pm 7$ \\
\hline & Peak & $15 \pm 8$ & $8 \pm 6$ & $23 \pm 9$ & $16 \pm 8$ \\
\hline & $0-20^{5}$ & $1 \pm 4$ & $-6 \pm 12$ & $-5 \pm 12$ & $8 \pm 7$ \\
\hline
\end{tabular}

\footnotetext{
' Net ileal venous and lumenal ammonia, and ileal glutamine extraction (A-V gln $\times$ flow rate) were collected in five animals infused with $3.0 \mathrm{ml} 0.9 \%$ $\mathrm{NaCl}$ and six animals infused with $116 \mathrm{mg} / \mathrm{kg} \mathrm{L-glutamine} \mathrm{in} 3.0 \mathrm{ml}$ of $0.9 \% \mathrm{NaCl}$. Infusion was made in the saphenous vein at 20 to $25 \mathrm{~min}$ of perfusion of the lumen with Earle's solution. Results are expressed as the mean \pm S.E. for each period. Net data were derived by subtracting the mean preinfusion value for each animal from the various postglutamine or saline infusion values (first $10 \mathrm{~min}$, peak, and first $20 \mathrm{~min}$ ).

${ }^{2}$ First 10 min during and after glutamine or saline infusion.

${ }^{3} P<0.025$ compared to saline control.

${ }^{4} P<0.05$ compared to saline control.

"First 20 min during and after glutamine or saline infusion.
} 


\section{PERFUSION WITH RESIN}

In four rats the Earle's + resin solution was perfused through the gut for $20 \mathrm{~min}$ to allow equilibration. Then $116 \mathrm{mg} / \mathrm{kg} \mathrm{L}$ glutamine in $3 \mathrm{ml} 0.9 \%$ saline was infused through the saphenous vein over $5 \mathrm{~min}$ and samples were collected for $20 \mathrm{~min}$. Three rats were infused with saline alone.

Figure 3 demonstrates that lumenal ammonia in the first $20 \mathrm{~min}$ during and after intravenous glutamine was approximately two and one-half times as much as when saline was infused intravenously. Of the ammonia measured in lumenal fluid 89 to $96 \%$ was bound to the resin.

Although glutamine extraction was not significantly greater in glutamine-treated animals when resin was perfused than when Earle's solution alone was perfused, there was a marked increase in lumenal ammonia in the presence of resin (Table 2). However, when resin was perfused, net ileal venous ammonia did not rise during the first 10 min during and after intravenous glutamine infusion $-8 \pm 14 \mathrm{nmole} \mathrm{NH}_{3} / \mathrm{min} / \mathrm{g}$ ileum). This net change in ileal venous ammonia was significantly different $(P<0.05)$ from the rise seen in the animals perfused with Earle's alone $(+28 \pm 9$

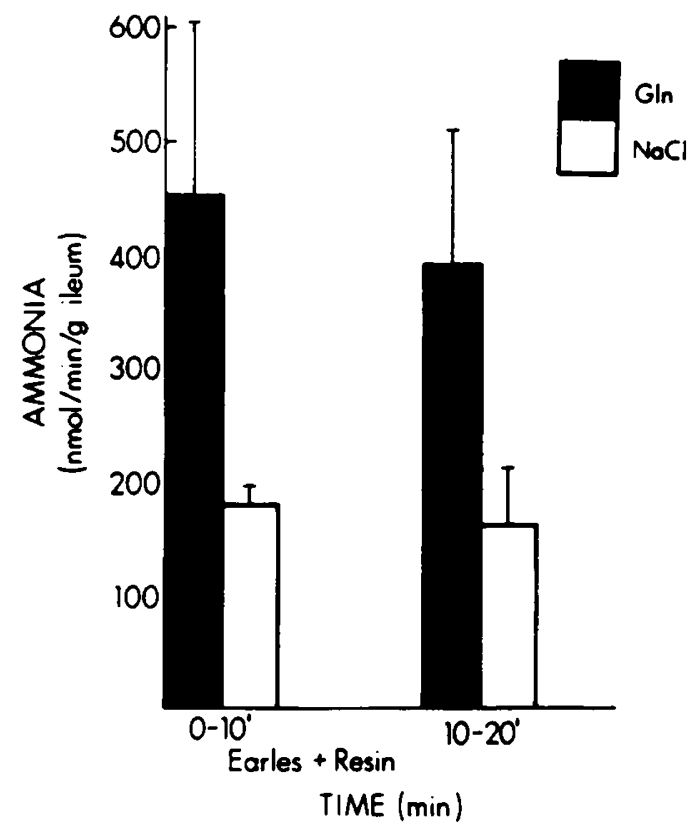

Fig. 3. Lumenal ammonia recovery during perfusion of the lumen with Earle's + resin solution. The resin was perfused for $20 \mathrm{~min}$ for equilibration. Then at time 0 in Figure 3, lumenal collections were started and 3.0 $\mathrm{ml}$ of $0.9 \% \mathrm{NaCl}$ alone (three animals) or $116 \mathrm{mg} / \mathrm{kg} \mathrm{L}$-glutamine (Gln) (four animals) were perfused through the saphenous vein. Resin was prepared and ammonia assayed as described in "Materials and Methods." nmole $\mathrm{NM}_{3} / \mathrm{min} / \mathrm{g}$ ileum). There was a trend for peak and first $20 \mathrm{~min}$ average net ileal venous ammonia to be lower during resin perfusion than perfusion with Earle's alone.

\section{DISCUSSION}

Our data demonstrate that ileal extraction of arterial glutamine provided ammonia to both the intestinal lumen and the venous circulation of the ileal segment. The perfusion system itself did not cause an artefactual increase in the lumenal and venous ammonia concentrations as no increases were noted in saline infused animals throughout the duration of the experiment. Twenty-eight percent of the ammonia produced during and after glutamine infusion was released into the lumen and the remainder was found in the ileal vein.

Although the amide nitrogen of glutamine was not labelled in our experiments, a preliminary report (7) suggested that the amide $\mathrm{N}^{15}$ nitrogen of glutamine injected intravenously into rats appears in the small intestine as ammonia. Windmueller and Spaeth (23) postulated that either hydrolysis of the glutamine amide nitrogen to yield ammonia or transfer of amide nitrogen to an organic receptor such as $\alpha$ ketoglutarate was likely to be an important first step in intestinal metabolism of glutamine. Subsequently, Pinkus and Windmueller (11) demonstrated that phosphate-dependent glutaminase I, (L-glutamine amidohydrolase EC 1.5.1.2) located in mitochondria of both villus and crypt cells, is the major glutamine-utilizing enzyme of small intestine of several species of laboratory mammals including rat. Other less active glutaminedegrading enzymes of rat small intestine include glutamine transaminase (EC 2.6.1.15)(7), carbayoyl phosphate synthetase (EC 2.7.2.9)(20), phosphoribosyl pyrophosphate amido-transferase (EC 2.4.2.14) (12) and fructose-6-phosphate amino-transferase (EC 2.6.1.16 = EC 5.3.1.19) (6). Although the enzymes of glutamine utilization in human small intestine have not been characterized it is clear that intestinal extraction of glutamine occurs in postabsorptive man (2). Both oral and intravenous glutamine administration to cirrhotic adults results in prompt increase in peripheral blood ammonia concentrations (14).

Several explanations are possible for the fact that the average net lumenal ammonia in the presence of intralumenal resin (378 $\pm 124 \mathrm{nmole} / \mathrm{min} / \mathrm{g}$ ileum) was greater than net glutamine extraction $(93 \pm 77 \mathrm{nmole} / \mathrm{min} / \mathrm{g}$ ileum). First, the peak of arterial ammonia extraction could have been missed, leading to underestimation of glutamine extracted. Second, the intestinal tissue itself might have provided ammonia from nonglutamine sources. Third, the resin could have adsorbed ammonia from the atmosphere. This latter explanation seems very unlikely, since parallel resin tubes exposed to room air in the laboratory were assayed for ammonia to give control values. Both these control values and the base line lumenal ammonia values were subtracted from lumenal ammonia during resin perfusion to give net lumenal ammonia.

The idea of using the gut as an ammonia trap is not new, but

Table 2. Effect of intralumenal resin on net $\mathrm{NH}_{3}$ production during intravenous glutamine infusion ${ }^{1}$

Ammonia recovered

\begin{tabular}{|c|c|c|c|c|}
\hline \multirow[b]{2}{*}{ Lumenal perfusion } & \multirow[b]{2}{*}{ Collection time (min) } & & & \multirow[b]{2}{*}{$\begin{array}{l}\text { Glutamine extraction } \\
\text { (nmole/min } / \mathrm{g} \text { ileum) }\end{array}$} \\
\hline & & $\begin{array}{c}\text { Ileal vein } \\
\text { (nmole } / \mathrm{min} / \mathrm{g} \text { ileum) }\end{array}$ & $\begin{array}{c}\text { Lumen } \\
\text { (nmole/min } / \mathrm{g} \text { ileum) }\end{array}$ & \\
\hline \multirow[t]{3}{*}{ Earle's + resin } & $0-10$ & $-8 \pm 14^{2}$ & $415 \pm 156^{3}$ & $55 \pm 52$ \\
\hline & Peak & $9 \pm 24$ & $416 \pm 123^{4}$ & $129 \pm 84$ \\
\hline & $0-20$ & $0 \pm 19$ & $378 \pm 124^{4}$ & $93 \pm 77$ \\
\hline \multirow[t]{3}{*}{ Earle's } & $0-10$ & $28 \pm 9$ & $13 \pm 8$ & $38 \pm 28$ \\
\hline & Peak & $59 \pm 25$ & $42 \pm 10$ & $158 \pm 60$ \\
\hline & $0-20$ & $34 \pm 20$ & $12 \pm 5$ & $86 \pm 40$ \\
\hline
\end{tabular}

\footnotetext{
${ }^{1}$ See footnote in Table 1 for explanation of net data.

${ }^{2} P<0.05$ (compared to value during perfusion of Earle's alone).

${ }^{3} P<0.01$.

${ }^{4} P<0.005$.
} 
arious methods of trapping the ammonia have been designed to rork in the colon, which was assumed to be the principle source $f$ ammonia in the gastrointestinal tract(15). An orally adminis:red cation-exchange resin could remove ammonia from the small Itestine, as well as large intestine. Small intestinal ammonia roduction (and glutamine extraction) may well be increased in yperammonemic states in man since plasma glutamine is often levated in such states (21). Hanson and Parsons(3) showed that Itestinal glutamine utilization in vascularly perfused small intesne of rat increased as glutamine concentration of the perfusate 'as raised. In our experiments peak intestinal glutamine extraction ith intravenous glutamine loading was almost 10 times as great $s$ in saline-infused animals and total ammonia (ileal venous plus Imenal) was significantly higher in the glutamine compared to re saline-infused animals.

Zuidema et al.(26) demonstrated that an oral cation-exchange esin could lower blood ammonia in dogs with porto-caval shunts rade hyperammonemic with administration of whole blood by astric tube, or by intravenous infusion of ammonium citrate. Our ata in the rat suggest that trapping of small intestinal ammonia lay play an important role in this response. Zuidema et al. (27) carned that long-term administration of the sodium-cycle exhange resin (used by both him and us) might lead to potassium epletion.

In summary, our experiments demonstrated the ability of an Itralumenal cation-exchange resin to effect a large increase in Imenal ammonia excretion during and after intravenous glutaline. At the same time the expected rise in venous $\mathrm{NH}_{3}$ (observed 1 other glutamine-infused rats not treated with resin) was preented. Cation-exchange resins may be useful additions to the eatment of hyperammonemic-hyperglutaminemic states in peiatric patients. Further studies will be needed to determine the ossible efficacy and safety of these resins in such patients.

\section{REFERENCES AND NOTES}

I. Batshaw, M. L., Brusilow, S., and Walser, M.: Long-term management of a case of carbamyl phosphate synthetase deficiency using keto-analogues and hydroxy-analogues of essential amino acids. Pediatrics 58: 227 (1976).

!. Felig, P., Wahren, J., Karl, I., Cerasi, E., Luft, R., and Kipnis, D.: Glutamine and glutamate metabolism in normal and diabetic subjects. Diabetes, 22: 573 (1973).

1. Hanson, P. J., and Parsons, D. S.: Metabolism and transport of glutamine and glucose in vascularly perfused small intestine rat. Biochem. J., 166: 509 (1977)

b. Hsia, Y. E.: Inherited hyperammonemic syndromes. Gastroenterology, 67: 347 (1974).

;. Karl, 1. E., and Kipnis. D.: (unpublished data)

j. Kaufman, M., Yip, C., and Knox, W. W.: Glucosamine 6-phosphate synthesis in normal and neoplastic rat tissues. Enzyme, 12: 537 (1971).

1. Kupchick, H. Z., and Know, W. E.: Assay of glutamine and its amino transferase with the Enol-Borate of phenylpyruvate. Arch. Biochem. Biophys., 136: 178 (1970).

3. Matsutaka, H., Aikawa, T.. Yamamoto, H., and Ishikawa, E.: Gluconeogenesis and amino acid metabolism III. Uptake of glutamine and output of alanine and ammonia by non-hepatic splanchnic organs of fasted rats and their metabolic significance. J. Biochem., 74: 1019 (1973).

9. Mossberg, S. M.: Ammonia absorption in hamster ileum: effect of $\mathrm{pH}$ and total $\mathrm{CO}_{2}$ on transport in everted sacs. Am. J. Physiol, 213: 1327 (1967).

10. Oberholzer, V. G., Schwarz, K. B., Smith, C. H., Dietzler, D. H., and Hanna, T. L.: Microscale modification of a cation-exchange column procedure for plasma ammonia. Clin. Chem., 22: 1976 (1976).

11. Pinkus, L., and Windmueller, H. G.: Phosphate-dependent glutaminase of small intestine: localization and role in intestinal glutamine metabolism. Arch. Biochem. Biophys., 182: 507 (1977).

12. Prajda. N., Morris, H. P., and Weber, G.: Imbalance of purine metabolism in hepatomas of different growth rates as expressed in behavior of xanthine oxidase (EC 1.2.3.2). Cancer Res., 36: 4639 (1976).

13. Price, J. B., Schwarz, G. F., Molavi, A., Britton, R. C., and Vorrhees, Jr., A. B. Mechanism and clinical significance of intestinal ammonia transport. Surg. Forum, 18: 331 (1967).

14. Rudman, D., Galambos, J., Smith, R. B., Salam, A. A., and Warren. D. Comparison of the effect of various amino acids upon the blood ammonia concentration of patients with liver disease. Am. J. Clin. Nutr., 26: 916 (1973).

15. Schenker, S., Breene, K. J., and Hoyempa, A. M.: Hepatic encephalopathy: Current status. Gastroenterology 66: 121 (1976).

16. Schwarz, K. B., Karl. I., and Alpers, D.: Ammonia metabolism by isolated perfused ileum. Gastroenterology (Abstract), 72: Al05 (1977).

17. Silen, W., Harper, H. A., Mawdsley, D. L., and Weirich, W. L.: Effect of antibacterial agents on ammonia production within intestine. Proc. Soc. Exp. Biol. Med., 88: 138 (1955).

18. Summerskill, W. H. J., and Wolpert, E.: Ammonia metabolism in the gut. Am. J. Clin. Nutr., 23: 633 (1970)

19. Summerskill, W. H. J., Aoyagi, T., and Evans, W. B.: Ammonia in the upper gastrointestinal tract of man: quantitations and relationship. Gut, 7: 497 (1966).

20. Tatibana, M., and Shigesada, K.: Two carbamyl phosphate synthetase of mammals: specific roles in control of pyrimidine and urea biosynthesis. Adv. Enzymol. Reg., 10: 249 (1972).

21. Walshe, J. M.: Disturbances of amino acid metabolism following liver injury. Q. J. Med., 22: 483 (1953).

22. Weber, F. L., and Veach, G. L.: The importance of small intestine in gut ammonium production in the fasting dog. Gastroenterology, 77: 235 (1979).

23. Windmueller, H. G., and Spaeth, A. E.: Uptake and metabolism of plasma glutamine by the small intestine. J. Biochem.. 249: 5070 (1974).

24. Windmuller, H. G., and Spaeth, A. E.: Identification of ketone bodies and glutamine as the major respiratory fuels in vivo for postabsorptive rat small intestine. J. Biochem., 253: 69 (1978)

25. Windmueller, H. G., and Spaeth, A. E.: Respiratory fuels and nitrogen metabolism in vivo in small intestine of fed rats. J. Biochem.. 255: 107 (1980)

26. Windmueller, H. G., and Spaeth, A. E.: Intestinal metabolism of glutamine and glutamate from the lumen as compared to glutamine from blood. Arch. Biochem. Biophys., 171: 662 (1975).

27. Zuidema, G. D., Fletcher, M. M., Burton, W. D., and Child, C. G. III: Oral cation exchange resin therapy for ammonia intoxication in dogs. Surgery, 52: 117 (1962).

28. The authors gratefully acknowledge the generous and skillful teaching of the techniques of intestinal perfusion by Dr. H. G. Windmueller and Mr. A Spaeth.

29. Requests for reprints should be addressed to: Kathleen B. Schwarz, M.D. Cardinal Glennon Memorial Hospital for Children, 1465 South Grand Boulevard, St. Louis, MO 63104 (USA).

30. This research was supported in part by Grants 5-T32-AM07130 and 5-RO1-AM14038 from the National Institute of Health.

31. Received for publication October 24, 1980.

32. Accepted for publication March 17, 1981. 